\title{
Molecular Characterization and mRNA Expression of ISP2 and ISP4 in the Large Yellow Croaker (Larimichthys Crocea) Under Acute Cold Stress
}

Baoying Qian ( $\nabla$ wutongye1979@126.com )

Taizhou University https://orcid.org/0000-0003-0066-6518

\section{Research Article}

Keywords: large yellow croaker, acute cold stress, ISP2, ISP4, mRNA expression

Posted Date: February 12th, 2021

DOI: https://doi.org/10.21203/rs.3.rs-183811/v1

License: (c) (i) This work is licensed under a Creative Commons Attribution 4.0 International License.

Read Full License 


\section{Abstract}

Ice structure proteins (ISPs), also known as antifreeze proteins, can lower the point of freezing by inhibiting the growth of ice crystals and protect organisms from freezing temperatures. The large yellow croaker (Larimichthys crocea) is an important warm-temperate marine fish in Chinese aquaculture. Only a few ISP studies have been reported in this fish to date. In this study, the CDNA of ISP2 were cloned and characterized, and mRNA expression of ISP2 and ISP4 was assessed in different tissues of the large yellow croaker under different periods of acute cold stress $(0,6,12,24,48$ and $72 \mathrm{~h}$, rewarming after 12 and $24 \mathrm{~h}$ ). We found that ISP2 CDNA is 861 bases in length, encoding a protein of 168 amino acid residues. The mRNA expression of ISP 2 and ISP 4 in tissues of large yellow croaker under different periods of acute cold stress changed significantly. In comparison with the control group, ISP2 expression increased dramatically in the heart (1,976 fold) and intestine ( 26 fold) after $3 \mathrm{~h}$ of acute cold stress and increased 43 fold in the spleen after $6 \mathrm{~h}$. ISP4 expression was up-regulated significantly in the brain (43 fold) and gill (376 fold) at $1 \mathrm{~h}$ acute cold stress, and increased 2,774 fold in the intestine at $3 \mathrm{~h}, 64$ fold in muscle and 141 fold in the spleen after rewarming for $1 \mathrm{~h}$ after $12 \mathrm{~h}$ acute cold stress. These results indicate that ISP2 and ISP4 may play an important role in the response of large yellow croaker to acute cold stress.

\section{Introduction}

Ice structure proteins (ISPs), also known as antifreeze protein, play a role in inhibiting the growth of ice crystals, modifying ice morphology and inhibiting the recrystallization of ice via adsorption-inhibition (DeVries and Wohlschlag, 1969; Lee and Kim, 2016). ISPs lower the point of freezing non-colligatively but do not change the point of melting through adsorption on the surface of ice crystals and then inhibit ice growth, which increases the temperature gap between melting point and freezing point, and this temperature gap is termed thermal hysteresis (TH) (Barrett, 2001). The larger the TH activity, the stronger the antifreeze activity of the ISPs. ISPs are vitally important for polar fish to prevent blood from freezing in subzero temperatures of seawater through depressing the freezing point from 1 to $1.2^{\circ} \mathrm{C}$ in the blood, allowing fish blood to flow during winter; simultaneously, other internal fluids are prevented from freezing by modifying the growth of ice crystals, which also protects cell membranes from ice crystal damage (DeVries, 1971; Hew and Yang, 1992; Fletcher et al., 2001; Harding et al., 2003). According to the composition of amino acids and structural characteristics, ISPs in fish are divided into five types, ISPI, ISP2, ISP3, ISP4 and antifreeze glycoproteins, and no homology exists between these types of ISPS (Zhong and Fan, 2002; Li and Ma, 2012).

ISP2 is found in Atlantic herring (Clupea harengus harengus), rainbow smelt (Osmerus mordax), Japanese smelt (Hypomesus nipponensis), longsnout poacher (Brachyopsis rostratus) and sea raven (Hemitripterus americanus) (Slaughter, et al., 1981; Ewart and Fletcher, 1990; Sorhannus, 2012). ISP2 is classified into two subtypes, $\mathrm{Ca}^{2+}$-dependent and $\mathrm{Ca}^{2+}$-independent, for instance, ISP2 produced by herring, rainbow smelt and Japanese smelt require $\mathrm{Ca}^{2+}$ for its antifreeze activity, while in the sea raven 
and longsnout poacher, the antifreeze activity of ISP2 can be performed without $\mathrm{Ca}^{2+}$ (Ewart and Fletcher, 1990; Ewart et al., 1992; Ewart et al., 1996; Yamashita et al., 2003).

ISP4 was first isolated from the serum of the north-temperate coastal water fish longhorn sculpin (Myoxocephalus octodecimspinosis) (Deng et al., 1997). Subsequently, researchers found that the physiological concentration of ISP4 in the blood of adult longhorn sculpins and shorthorn sculpins was lower than any other type of ISP, and could not conduct antifreeze activity (Deng and Laursen, 1998; Zhao et al., 1998; Gauthier et al., 2008). Based on these findings, Gauthier et al. (2008) speculated that ISP4 may not be a key antifreeze protein in the blood of polar fish when other types of antifreeze protein are present. Surprisingly, in addition to polar fish, ISP4 is also found in warm-temperate fish and freshwater fish (Nishimiya et al., 2008; Zhang et al., 2009; Kim, 2015; Lee and Kim, 2016). These reports indicate that ISP4 may have other effects as well as antifreeze activity in warm-temperate fish.

Large yellow croaker is a warm-temperate marine fish that inhabits the north of the South China Sea and the East China Sea coastal waters of China. Since 1985, with the success of artificial breeding techniques in this species, it is now mainly farmed in single net cages (Hong and Zhang, 2003). The temperature of water is a key factor for fish and is closely related to growth, reproduction and immune metabolism. Extreme changes in water temperature are damaging for fish especially net cage farmed fish for they cannot escape from harmful regions of the sea. Large yellow croaker usually grow in water temperature from $10 \sim 32^{\circ} \mathrm{C}$, rapid growth occurs in water temperatures $18 \sim 25^{\circ} \mathrm{C}$, whereas survival may be threatened in water temperature higher than $34^{\circ} \mathrm{C}$ or lower than $7^{\circ} \mathrm{C}$ (Chen and $\mathrm{Wu}, 2011$ ). On the basis of comparative transcriptome analysis in the liver of large yellow croaker under acute cold stress after $12 \mathrm{~h}$ conducted in our laboratory (data available at SRA http://www.ncbi.nlm.nih.gov/geo/query/acc.cgi? acc=GSE67756), we found that the expression of ISP2 was significantly up-regulated and the expression of ISP4 increased but with insignificance (Qian and Xue, 2016). In this study, we conducted a molecular characterization of ISP2 and ISP4, mRNA expression of these two genes was observed in liver, muscle, gill, heart, spleen, intestine, brain and kidney of 1-year-old large yellow croaker under acute cold stress for $1,3,6,12,24,48$ and $72 \mathrm{~h}$, rewarming 1 and $3 \mathrm{~h}$ after $12 \mathrm{~h}$ cold stress ( $12 \mathrm{f} 1 \mathrm{~h}$ and $12 \mathrm{f} 3 \mathrm{~h}$ ) and rewarming $1 \mathrm{~h}$ after $24 \mathrm{~h}$ cold stress ( $24 \mathrm{f} 1 \mathrm{~h}$ ). Our objectives were (1) to analyze the molecular properties of type-II ISP in large yellow croaker and (2) investigate the spatiotemporal expression of ISP2 and ISP4 in large yellow croaker under acute cold stress.

\section{Materials And Methods}

\subsection{Animals and acute cold stress}

Large yellow croaker (mean weight $80 \pm 0.7 \mathrm{~g}$ ) were purchased from mariculture in Xiangshan Bay (Zhejiang, China) and maintained in a laboratory at the Ningbo Ocean and Fishery Science Technology Innovation Base. Fish were randomly divided into eight groups and acclimated in $500 \mathrm{~L}$ plastic aerated tanks with flow-through seawater at $28^{\circ} \mathrm{C}$ under $14 \mathrm{~h}$ light/ 10 dark photoperiod for 7 days ( 30 fish in each tank and eight tanks in total). They were fed with granulated feed for large yellow croakers twice per day 
until 1 day before the experiment. A total of 150 fish in five tanks were treated with acute cold stress using a seawater chiller until the seawater temperature dropped to $14^{\circ} \mathrm{C}$ in $2 \mathrm{~h}$ (cold stress group). The other 90 fish with no treatment were cultured in another three tanks (control group). After $12 \mathrm{~h}$ and $24 \mathrm{~h}$ acute cold stress, 30 fish were immediately transferred to a tank with the water temperature at $28^{\circ} \mathrm{C}$ for the rewarming experiment. Tissues including liver, liver, muscle, gill, heart, spleen, intestine, brain and kidney were harvested from three fish at each time point $(1,3,6,12,24,48,72,12 f 1,12 f 3$ and $24 f 1 \mathrm{~h})$ in the acute cold stress and control groups. All sampled tissues harvested in this experiment were snapfrozen in liquid nitrogen and stored at $-80^{\circ} \mathrm{C}$. The protocols of all experiments meet the "Zhejiang Laboratory Animal Management" guideline established by the Zhejiang Provincial Department of Science and Technology on the Use and Care of Animals.

\subsection{Total RNA extraction and cDNA synthesis}

Total RNA was extracted from the tissues harvested in each time point (including three control and acute cold stressed fish) using a Tissue RNA Kit (Omega, Georgia, USA) following the manufacturer's instructions. The total RNA was quantified with NanoDrop ND-1000 (Nanodrop Technologies) and RNA integrity (RIN) was assessed with an Agilent 2100 Bioanalyzer. The RIN values of all RNA samples were $\geq 8$. All extracted RNA was stored at $-80^{\circ} \mathrm{C}$. cDNA was synthesized using a PrimeScript RT reagent Kit with a gDNA Eraser (TaKaRa, Tokyo, Japan) according to the manufacturer's instruction, and cDNA was stored at $-20^{\circ} \mathrm{C}$ for further experimental analysis.

\subsection{Cloning of the full cDNA length of ISP2 and ISP4}

A partial cDNA length of ISP2 was obtained from the liver transcriptome data of large yellow croaker, which was investigated earlier in our laboratory, and the detailed sequence information can be found at http://www.ncbi.nlm.nih.gov/geo/query/acc.cgi?acc=GSE67756 (Qian and Xue, 2016). Gene-specific primers for 5'- and 3'-RACE were designed based on the aforementioned partial sequences (Table 1). 5'and 3'-RACE was used to obtain sequences of the 5'- and 3'-untranslated terminal regions of ISP2 using a SMARTer RACE 5'/3' Kit (TaKaRa, Tokyo, Japan) according to the kit manufacturer's instructions. The fulllength CDNA of ISP2 was assembled using overlapped fragments. 
Table 1

Primers for quantitative real time PCR.

\begin{tabular}{|ll|}
\hline Gene & Primer sequence $\left(\mathbf{5}^{\prime} \mathbf{}^{\mathbf{3}} \mathbf{}^{\prime}\right)$ \\
\hline ISP2 & F: GCTGACTGTGTCCGCATTTC \\
\hline ISP2 & R: ACCCAGAGAGCGACAGTTTG \\
\hline ISP4 & F: TCTTGGAACTTAGCGGCCAG \\
\hline ISP4 & R: CTTTGCAGAAGAGCTCCCCA \\
\hline B-actin & F: TCGGTATGGAATCTTGCG \\
\hline$\beta$-actin & R: GTATTTACGCTCAGGTGGG \\
\hline ISP2-GSP5 & GATTACGCCAAGCTTGACCAGCCACCAGGACAAGATGCGG \\
\hline ISP2-GSP3 & GATTACGCCAAGCTTCCGTCCGTCTGTGCCAAGGAAATCT \\
\hline
\end{tabular}

\subsection{Sequence and phylogenetic analysis of ISP2}

The molecular analysis methods of Feng et al. (2019) were used in this study to analyze ISP2: 1) BLAST was used to analyze the nucleotide sequence and deduced amino acid sequence of ISP2 (http://www.ncbi.nlm.nih.gov/blast); 2) SignaliP 4.1 Server was used to predict the ISP2 signal peptide (http://www.cbs.dtu.dk/services/SignalP); 3) SMART was used in domain prediction (http://www.cbs.dtu.dk/services/SignalP); 4) and MEGA 6.0 software was used to analyze the phylogenetic tree.

\subsection{Spatiotemporal expression analysis of ISP2 and ISP4}

Quantitative real-time PCR (qRT-PCR) was used to investigate the spatial and temporal expression of ISP2 and ISP4. The first-stand cDNA from different tissues of the control fish $(n=3)$ as well as acute cold stressed fish were diluted 1:5 with sterile and DNase/RNase free distilled water and used as qRT-PCR templates. Primers were designed for the qRT-PCR of ISP2, ISP4 and $\beta$-actin (Table 1), and five 10-fold serial dilutions of cDNAs of all tissues were used to assess the amplification efficiency of the primers. Primers with an amplification efficiency between 0.90-1.05 were chosen for further experiments. The qRT-PCRs were performed in a total volume of $20 \mu \mathrm{l}$ on a CFX96 Real-Time PCR System (Bio-Rad, California, USA), and the thermal cycling conditions were as follows: $95^{\circ} \mathrm{C}$ for $10 \mathrm{~min}, 40$ cycles of $95^{\circ} \mathrm{C}$ for $15 \mathrm{~s}, 58^{\circ} \mathrm{C}$ for $20 \mathrm{~s}, 72^{\circ} \mathrm{C}$ for $20 \mathrm{~s}$, followed by a melting curve. All samples were amplified in triplicate repeats, and the relative expression levels of ISP 2 and ISP 4 in each sample were normalized by $\beta$-actin quantification applying the method of $2^{-\triangle \Delta C T}$ (Schmittgen and Livak, 2008). One-way analysis of variance was used to determine the statistical significance by using SPSS software (Version 21), and a significant difference was considered at $P<0.05$ and a highly significant difference was considered at $P$ $<0.01$

\section{Results}




\subsection{Molecular characterization of ISP2}

The full-length cDNA of ISP2 (GenBank accession number: 2370265) was 861 bp, including a 77 bp 5'untranslated region (UTR), a 301 bp 3'-UTR with an AATAAA signal and a poly (A) tail, and a 507 bp open reading frame (ORF) encoding a putative protein with 168 amino acid residues, which contains a putative signal peptide with 18 amino acid residues (Fig. 1).

By using SMART analysis, we deduced that the ISP2 amino acid sequence contains a C-type lectin (CLECT or CTL) domain or carbohydrate-recognition domain (CRD), which starts at position 40 and ends at position 165 aa. The ISP2 of the large yellow croaker has low homology in multiple sequence alignment with the ISP2 of 11 other fish species, and the highest homology has $76 \%$ identity (Amphiprion ocellaris) (Fig. 1). The phylogenetic tree constructed in this study was based on the ISP2 amino acid sequences of 12 fish species (Fig. 2). The ISP2 of the large yellow croaker was the furthest distance from that of other fish species.

\subsection{ISP2 mRNA spatiotemporal expression during the acute cold stress}

The spatiotemporal expression levels of ISP 2 in large yellow croaker under acute cold stress are shown in Fig. 3. In liver tissue, ISP2 mRNA expression increased approximately at 3, 6, 48, 72, $12 \mathrm{f} 3$ and $24 \mathrm{f} 1 \mathrm{~h}$ after acute cold treatment in comparison to the control $(P<0.01)$. Especially at $3 \mathrm{~h}$ after cold treatment, the expression of ISP2 increased to 8.23-fold in comparison to the control but decreased significantly at $12 \mathrm{~h}$ $(P<0.01)$. In muscle tissue, the initial expression of $I S P 2$ decreased significantly at $1 \mathrm{~h}$ after acute cold treatment and then was up-regulated remarkably at $3,6,12 \mathrm{~h}$, and down-regulated again at 24 and $72 \mathrm{~h}$ $(P<0.01)$. In brain tissue, ISP2 mRNA expression increased significantly at $1 \mathrm{~h}$ and $72 \mathrm{~h}$ in the cold stress group with 9.95 and 55.57-fold changes, respectively, compared to the control group $(P<0.01)$. ISP2 mRNA expression decreased remarkably at $48 \mathrm{~h}$ and $12 \mathrm{f} 1 \mathrm{~h}(P<0.01)$, and no changes occurred throughout the other sampling time points in comparison to control $(P \geq 0.05)$. In heart tissue, the expression of ISP2 was up-regulated significantly at $1,3,6,48,72,12 \mathrm{f} 3$ and $24 \mathrm{f} 1 \mathrm{~h}(P<0.01)$. In particular, at $3 \mathrm{~h}$ after cold treatment, the increased 1,976.29-fold compared to the control group. ISP2 mRNA expression decreased at $12 \mathrm{f} 1 \mathrm{~h}(0.01 \leq P<0.05)$, and no expression occurred at $12 \mathrm{~h}(0.01$-fold $)$. In spleen tissue, at $6,12 \mathrm{f} 1$ and $12 \mathrm{f} 3 \mathrm{~h}$ after acute cold stress, the expression of ISP2 increased significantly by $43.5,8.41$ and 10.99 -fold $(P<0.01)$, respectively, but was down-regulated remarkably at 3 and $24 \mathrm{~h}(P$ $<0.01)$. In kidney tissue, there were no changes in the expression of ISP2 from 1 to $72 \mathrm{~h}$ including $12 \mathrm{f} 1$ and $12 \mathrm{f} 3 \mathrm{~h}$ after cold treatment $(P \geq 0.05)$, but at $24 \mathrm{f} 1, I S P 2$ mRNA expression significantly increased 5.38 -fold relative to the control group $(P<0.01)$. In gill tissue, the initial expression of $I S P 2$ was decreased significantly during 1 to $12 \mathrm{~h}$, then increased remarkably during 24 to $72 \mathrm{~h}$, and decreased significantly after rewarming $(12 \mathrm{f} 1,12 \mathrm{f} 3$ and $24 \mathrm{f} 1 \mathrm{~h})(P<0.05)$. In intestinal tissue, ISP2 mRNA expression increased highly significantly by 26.62 and 6.09 -fold at 3 and $12 \mathrm{~h}$, respectively, and was highly significantly decreased at 6 and $24 \mathrm{~h}(P<0.01)$. The expression of ISP2 was increased significantly at $72,12 \mathrm{f} 1$ and 
$12 \mathrm{f3}(0.01 \leq P<0.05)$, and no changes occurred throughout the other sampling times relative to the control fish $(P<0.05)$.

\subsection{ISP4 mRNA spatiotemporal expression during acute cold stress}

The spatiotemporal expression levels of ISP4 in large yellow croaker under acute cold stress are shown in Fig. 4. In liver tissue, ISP4 mRNA expression increased significantly at 48 and $24 \mathrm{f} 1 \mathrm{~h}$ and decreased significantly at 6 and $72 \mathrm{~h}$ after acute cold stress $(P<0.05)$. There were no changes in the expression of ISP4 at other sampling time points in comparison to the control $(P \geq 0.05)$. In muscle tissue, there was no ISP4 mRNA expression at 1, 24 and $24 \mathrm{f} 1 \mathrm{~h}$, but expression increased dramatically at 3, 48 and $12 \mathrm{f} 1 \mathrm{~h}$ $(0.01 \leq P<0.05)$, particularly at $12 \mathrm{f} 1 \mathrm{~h}$ after acute cold treatment, the expression of ISP4 was up to 64.02fold relative to the control. In brain tissue, the expression of ISP4 was up- or down-regulated significantly throughout sampling time points except at $12 \mathrm{f} 3 \mathrm{~h}$ there was no change compared to the control $(P<$ 0.05). At $1 \mathrm{~h}$ after acute cold treatment, ISP4 mRNA expression was increased by 42.81 -fold relative to the control. In heart tissue, ISP4 mRNA expression decreased significantly during the first 1 to $3 \mathrm{~h}$ compared to the control but increased significantly at 48 to $72 \mathrm{~h}$, including the sampling time point $12 \mathrm{f} 1$ and $12 \mathrm{f} 3 \mathrm{~h}$ $(P<0.01)$. In spleen tissue, the expression of ISP4 significantly changed at sampling time point 6 and $12 \mathrm{f3} \mathrm{h}(P<0.05)$, particularly at $12 \mathrm{f} 1 \mathrm{~h}$, the expression of ISP4 mRNA was up to 141.27-fold that of the control group. In kidney tissue, ISP4 mRNA expression was significantly increased at 6, 12, 48 and 72 h, and decreased significantly at $3,24,12 \mathrm{f3}$ and $24 \mathrm{f} 1 \mathrm{~h}$ in comparison to the control fish $(P<0.05)$. In gill tissue, ISP4 mRNA expression increased by 375.84-fold that of the control, and increased significantly at $12,24,72$ and $24 \mathrm{f} 1 \mathrm{~h}$, but decreased significantly at 3,48 and $12 \mathrm{f} 3 \mathrm{~h}(P<0.05)$. In intestinal tissue, the expression of ISP4 decreased significantly at 6, 12, 24, $12 \mathrm{f} 1$ and $12 \mathrm{f} 3 \mathrm{~h}$, and increased significantly at 1 , 3,48 and $24 \mathrm{f} 1 \mathrm{~h}$, especially at the sampling time point $3 \mathrm{~h}$, ISP4 mRNA expression was up to 2,774.02fold that of the control group $(P<0.05)$.

\section{Discussion}

Cold stress, especially in winter, is a key limiting factor in warm-temperate marine fish, including the large yellow croaker, which is cultured in net cages. In recent years, researchers have sought to understand the molecular response to cold stress in the large yellow croaker, in studies including the gene expression of CIRP(Miao et al, 2017), HSP27, HSP30, HSP47, HSP90, caspase-1 and caspase-7(Yang, 2011). Our previous study found that ISP2 mRNA expression was significantly increased after $12 \mathrm{~h}$ cold stress in the liver of large yellow croaker, but there was no significant change in ISP4 compared to the control group (Qian and Xue, 2016). In this study, mRNA expression of ISP2 and ISP4 were investigated in eight tissues

of the large yellow croaker during periods of cold stress $(1,3,6,12,24,48$ and $72 \mathrm{~h}$ ) and rewarming (12f1, $12 \mathrm{f} 3$ and $24 \mathrm{f} 1 \mathrm{~h}$ ). Results showed that the expression changes of these two genes during stress are tissue and time-dependent. 
As mentioned earlier, type-II ISPs are only found in a few fish species (Yang, 2016), and almost no studies focus on ISP2 in warm-temperate fish. The brain, neural centre, is the tissue in fish that responds to changes in temperature the fastest and is an important tissue in the regulation of temperature (Crawshaw et al, 1985; Xu, 2011). In this study, encephalic mRNA levels of ISP2 increased significantly at $1 \mathrm{~h}$ cold stress, while no changes in ISP2 expression occurred in other tissues such as liver, heart, kidney and intestine. This seems to confirm that compared to other tissues the brain in fish responds first to cold stress. At $3 \mathrm{~h}$ of cold stress, ISP2 mRNA expression does not change in the brain but increased dramatically in the liver (8.23-fold), muscle (21.6-fold), and intestine (26.62-fold), especially in the heart, mRNA levels of ISP2 increased by 1796.29 -fold compared to the control group. A possible reason for this result could be that cardiomyocytes receive certain signals from central nerves, which promote ISP2 expression dramatically to alleviate the damage of $3 \mathrm{~h}$ acute cold stress on cardiomyocytes, and a similar response mechanism occurs in other tissues. It should be noted that, in this study, prolonged cold stress has no effect on the expression of ISP2 in the brain of large yellow croaker until $48 \mathrm{~h}$, and on the contrary, significant changes occurred in ISP2 mRNA expression from 3 to $48 \mathrm{~h}$ in other tissues including liver, muscle, spleen, heart, gill and intestine. It is possible that ISP2 synthesized in the brain of large yellow croaker at $1 \mathrm{~h}$ cold stress is enough to protect nerve cells from subsequent cold stress, and in other tissues, ISP2 must be synthesized constantly to achieve protection in prolonged cold stress. In our study, a strange phenomenon occurred after rewarming, the expression of ISP2 in some tissues including liver (12f3 and 24f1), muscle (12f3 and 24f1), heart (12f3 and 24f1), spleen (12f1 and 12f3), kidney (24f1) and intestine (12f1 and 12f3) were significantly increased. It is not clear why rewarming should have such an effect in these tissues. Maybe it is a compensation mechanism in response to the warmer water temperature.

ISP4 (also known as AFP IV) is different from ISP2 and has been detected in warm-water fishes as well as cold-water species, its function is controversial (Mao et al, 2018). In addition, the mRNA expression of ISP4 has only been investigated in the liver of large yellow croaker, and the protein of ISP4 has no remarkable antifreeze activity (Zhang et al, 2009). Unlike in the research by Zhang et al., we found that the mRNA expression of ISP4 was significantly increased in tissues of large yellow croaker that were subjected to acute cold stress and rewarming, including the liver ( $48 \mathrm{~h}$ cold stress and rewarmed $1 \mathrm{~h}$ after $24 \mathrm{~h}$ cold stress), muscle ( 3 and $48 \mathrm{~h}$ cold stress and rewarmed $1 \mathrm{~h}$ after $12 \mathrm{~h}$ cold stress), brain $(1,6,12$, 24 and $72 \mathrm{~h}$ cold stress and rewarmed $1 \mathrm{~h}$ after $24 \mathrm{~h}$ cold stress), spleen (12, 24, 48 and $72 \mathrm{~h}$ cold stress and rewarmed $1 \mathrm{~h}$ after 12 and $24 \mathrm{~h}$ cold stress), gill $(1,12,24$ and $72 \mathrm{~h}$ cold stress and rewarmed $1 \mathrm{~h}$ after $24 \mathrm{~h}$ cold stress), kidney $(6,12,48$ and $72 \mathrm{~h}$ cold stress), intestine (1, 3 and $48 \mathrm{~h}$ cold stress and rewarmed $1 \mathrm{~h}$ after $24 \mathrm{~h}$ cold stress) and heart ( 48 and $72 \mathrm{~h}$ cold stress and rewarmed 1 and $3 \mathrm{~h}$ after $12 \mathrm{~h}$ cold stress). Interestingly, ISP4 expression was remarkably increased in brain, gill and intestine at $1 \mathrm{~h}$ acute cold stress, especially in gill tissue, mRNA expression was increased by 375.84 -fold compared to the control group. This could indicate that the brain, gills and intestine were more sensitive to cold stress, and ISP4 may play an important role in the protection of these three tissues from the influence of cold at $1 \mathrm{~h}$. A number of studies have observed an evolutionary relationship between ISP4 and apolipoproteins (for example ApoA and ApoE) (Deng et al, 1997; Gauthier et al, 2008; Zhang et al, 2009; Mao et al, 2018). 
In our study, the mRNA expression of ISP4 was highly up-regulated (2774.02-fold) in the intestine at $3 \mathrm{~h}$, but there were no significant effects or it was significantly decreased in other tissue including liver, brain, spleen, gill, kidney and heart. It is not clear why changes in ISP4 mRNA expression are different in these tissues in the same fish treated with acute cold stress after $3 \mathrm{~h}$. One possibility could be that ISP4 functions as an apolipoprotein in the intestine after $3 \mathrm{~h}$ of cold stress.

In summary, the expression of ISP 2 and ISP4 mRNA changed in many tissues of the large yellow croaker after acute cold stress and was time and tissue-dependent. The brain, a high-level central neural system, was a sensitive tissue which responded to acute cold stress within a short time $(1 \mathrm{~h})$. The expression of ISP2 and ISP4 were both significantly increased at $1 \mathrm{~h}$ in the brain, which may indicate that ISP2 and ISP4 proteins could be synthesized in large yellow croaker while the fish is undergoing acute cold stress and protect the central neural system from cold stress. It should be noted that some differences occurred in the level of mRNA expression of these two genes at the same stress time in the same tissue. We do not know why cold stress and rewarming should have such effects in mRNA expression of ISP2 and ISP4 within the same tissue at the same duration of cold stress. Could it mean that ISP2 and ISP4 have a synergistic effect to protect fish from cold stress of extreme differences in temperature? Further studies should be conducted to fully understand the function of ISP2 and ISP4 in this warm temperature fish.

\section{Declarations}

\section{Acknowledgements}

This project was funded by Zhejiang Provincial Natural Science Foundation of China (Grant No. LGN18C190007) and Taizhou science and technology project (Grant No. 1901ny09). We thank International Science Editing for language editing this manuscript.

\section{Declarations}

We declare that we have no conflicts of interest.

\section{References}

1. DeVries, A.L., Wohlschlag, D.E., 1969. Freezing resistance in some Antarctic fishes. Science,163(3871):1073-1075. https://Doi:10.1126/science.163.3871.1073

2. Lee, J.K., Kim, H.J., 2016. Cloning, expression, and activity of type IV antifreeze protein from cultured subtropical olive flounder (Paralichthys olivaceus). Fisheries \& Aquatic Sciences, 19(1):33. https://Doi: 10.1186/s41240-016-0033-9

3. Barrett, J., 2001. Thermal hysteresis proteins. The international journal of biochemistry \& cell biology, 33:105-117. https://Doi: 10.1016/S1357-2725(00)00083-2 
4. DeVries, A.L., 1971. Glycoproteins as biological antifreeze agents in Antarctic fishes. Science, 172(3988):1152-1155. https://Doi: 10.1126/science.172.3988.1152

5. Fletcher, G.L., Hew, C.L., Davies, P.L., 2001. Antifreeze proteins of teleost fishes. Annual Review of Physiology, 63(1):359-390. https://Doi: 10.1146/annurev.physiol.63.1.359

6. Zhong, Q.W., Fan, Y.J., 2002. Advances in fish antifreeze protein research. Acta Biochimica et Biophysica Sinica, 34(2):124-130. https://Doi: 10.1007/BF02943277

7. Li, W.K., Ma, C.S., 2012. Present properties, mechanism and prediction of antifreeze proteins. Chinese Bulletin of Life Sciences, 24(10):1089-1097. https://Doi: 10.13376/j.cbls/2012.10.016

8. Hew, C.L., Yang, D.S., 1992. Protein interaction with ice. Eruopean Journal of Biochemistry, 203(12):33-42. https://Doi: 10.1007/978-3-642-78046-2_3

9. Harding, M.M., Anderberg, P.I., Haymet, A.D.J., 2003. Antifreeze glycoproteins from polar fish. Eruopean Journal of Biochemistry, 270(7):1381-1392. https://Doi: 10.1046/j.14321033.2003.03488.x

10. Slaughter, D., Fletcher, G.L., Ananthanarayanan, V.S., Hew, C.L., 1981. Antifreeze proteins from the sea raven, hemitripterus americanus. Further evidence for diversity among fish polypeptide antifreezes. Journal of Biological Chemistry, 256(4):2022-2026. https://Doi: doi:10.1016/0165-022X(81)90075-0

11. Ewart, K.V., Fletcher, G.L., 1990. Isolation and characterization of antifreeze proteins from smelt (Osmerus mordax) and Atlantic herring (Clupea harengus harengus). Canadian Journal of Zoology, 68:1652-1658. https://Doi: 10.1139/z90-245

12. Sorhannus, U., 2012. Evolution of type II antifreeze protein genes in teleost fish: A complex scenario involving lateral gene transfers and episodic directional selection. Evolutionary Bioinformatics, 8:535-544. https://Doi: 10.4137/EBO.S9976

13. Ewart, K.V., Rubinsky, B., Fletcher, G.L., 1992. Structural and functional similarity between fish antifreeze proteins and calcium-dependent lectins. Biochemical and Biophysical Research Communications, 185(1):335-340. https://Doi: 10.1016/S0006-291X(05)90005-3

14. Ewart, K.V., Yang, D.S., Ananthanarayanan, V.S., Fletcher, G.L., Hew, C.L., 1996. Ca ${ }^{2+}$-dependent antifreeze proteins. Modulation of conformation and activity by divalent metal ions. Journal of Biological Chemistry, 271(28):16627-16632. https://Doi: 10.1074/jbc.271.28.16627

15. Yamashita, Y., Miura, R., Takemoto, Y., Tsuda, S., Kawahara, H., Obata, H., 2003. Type II antifreeze protein from a midlatitude freshwater fish, Japanese smelt (Hypomesus nipponensis). Bioscience and Biochemistry, 67(3):461-466. https://Doi: 10.1271/bbb.67.461

16. Deng, G., Andrews, D.W., Laursen, R.A., 1997. Amino acid sequence of a new type of antifreeze protein, from the longhorn sculpin Myoxocephalus octodecimspinosis. FEBS letters, 402(1):0-20. https://Doi.org/10.1016/S0014-5793(96)01466-4

17. Deng, G., Laursen, R.A., 1998. Isolation and characterization of an antifreeze protein from the longhorn sculpin, Myoxocephalus octodecimspinosis. Biochimica et Biophysica Acta, 1388(2):305314. https://Doi: 10.1016/S0167-4838(98)00180-0 
18. Zhao, Z.H., Deng, G.J., Lui, Q.M., Laursen, R.A., 1998. Cloning and sequencing of cDNA encoding the LS-12 antifreeze protein in the longhorn sculpin, Myoxocephalus octodecimspinosis. Biochimica et Biophysica Acta, 1382:177-180. https://Doi.org/10.1016/S0167-4838(97)00197-0

19. Graham, L.A., Lougheed, S.C., Ewart, K.V., Davies, P.L., 2008. Lateral transfer of a lectin-like antifreeze protein gene in fishes. PLoS One, 3:e2616. https://Doi: 10.1371/journal.pone.0002616

20. Zhang, X., Wu, H.Z., Wei, W., Xu, H.Y., Zhang, Y.X., 2009. Cloning expression and characterization of antifreeze protein IV-like gene from large yellow croaker (Pseudosciaena Crocea). Food and Drug, 11(9):15-19.

21. Nishimiya, Y., Yasuhiro, M., Hirano, Y., Kondo, H., Miura, A., Tsuda, S., 2008. Mass preparation and technological development of an antifreeze protein. Synthesiology English Edition, 1(1):7-14. https://Doi.org/10.5571/syntheng.1.7

22. Kim, H.J., 2015. Antifreeze activity in temperate fish from the East Sea, Korea. Fisheries \& Aquatic Science, 18(2):137-142. https://Doi: 10.5657/FAS.2015.0137

23. Hong, W.S., Zhang, Q.Y., 2003. Review of captive bred species and fry production of marine fish in China. Aquaculture, 227(1):305-318. https://Doi .org/10.1016/S0044-8486(03)00511-8

24. Chen, F., Wu, C.W., 2011. Industrial situation and development countermeasure of cultivation of large yellow croaker in Zhejiang Province. Zhejiang Ocean University Nature Science Education, 30(3):259263.

25. Qian, B.Y., Xue, L.Y., 2016. Liver transcriptome sequencing and de novo annotation of the large yellow croaker (Lamichthys crocea) under heat and cold stress. Marine Genomics, 25:95-102. https://Doi: 10.1016/j.margen.2015.12.001

26. Schmittgen, T.D., Livak, K.J., 2008. Analyzing real-time PCR data by the comparative CT method. Nature Protocols, 3(6):1101-1108. https://Doi:10.1038/nprot.2008.73

27. Miao, L., Li, M.Y., Chen, Y.Y., Hu, M., Chen, J., 2017. Cloning of cold inducible RNA-binding protein (CIRP) gene in Larimichthys crocea and its expression analysis under cold treatments. Journal of Fisheries of China, 41(4): 481-489. https://Doi:10.11964/jfc.20160410364

28. Yang, Q.L., 2011. Response characterization of some HSP and caspase genes of large yellow croaker to temperature stress. Xiamen: Jimei University.

29. Yang, M., 2016. A preliminary study on the functions of a multimer type III antifreeze protein in low temperature tolerance. Shanghai: Shanghai Ocean University.

30. Xu, L.H., 2011. Screening, full-length cDNA cloning and function prediction of cold-acclimation differential expression candidate genes in the brain of commom carp (Cyprinus carpio). Shanghai: Shanghai Ocean University.

31. Crawshaw, L., Grahn, D., Wollmuth, L., Simpson, L., 1985. Central nervous regulation of body temperature in vertebrates: Comparative aspects. Pharmacology \& Therapeutics, 30(1): 19-30. https://doi.org/10.1016/0163-7258(85)90045-2

32. Mao, M.G., Chen, Y., Liu, R.T., Lv, H.Q., Gu, J., Jiang, Z.Q., Jiang, J.L., 2018. Transcriptome from Pacific cod liver reveals types of apolipoproteins and expression analysis of AFP-IV, structural analogue with 
mammalian Apop-I. Comparative Biochemistry and physiology. Part D, Genomics \& Proteomics, 28 : 204-212. https://Doi: 10.1016/j.cbd.2018.10.001

33. Deng, G.J., Andrews, D.W., Laursen, R.A., 1997. Amino acid sequence of a new type of antifreeze protein, from the longhorn sculpin Myoxocephalus octodecimspinosis. Febs Letters, 402(1): 17-20. https://Doi: 10.1016/S0014-5793(96)01466-4

34. Gauthier, S.Y., Scotter, A.J., Lin, F.H., Baardsnes, J., Fletcher, G.L., Davies, P.L., 2008. A re-evaluation of the role of type IV antifreeze protein. Cryobiology, 57(3): 292-296. https://Doi:

10.1016/j.cryobiol.2008.10.122

\section{Figures}

Larimichthys crocea

Notolabrus celidotus XP_034532653

Archocentrus centrarchus XP_030608958

Micropterus salmoides QFE 32160

Morone saxatilis XP-035530986

Anoplopoma fimbria ACQ58279

Cyclopterus lumpus XP_034412858

Poecilia mexicana XP $0 \overline{14} 831463$

Stegastes partitus XP_008303506

Acanthochromis polyacanthus XP_022077912

Amphiprion ocellaris XP 023136616

Oreochromis aureus XP_031582522

Consensus

\section{Larimichthys crocea}

Notolabrus celidotus XP 034532653

Archocentrus centrarchus XP_030608958

Micropterus salmoides QFE32160

Morone saxatilis XP-035530986

Anoplopoma fimbria ACQ58279

Cyclopterus lumpus XP_034412858

Poecilia mexicana XP_014831463

Stegastes partitus XP 008303506

Acanthochromis polyacanthus XP_022077912

Amphiprion ocellaris XP $0231366 \overline{1} 6$

Oreochromis aureus XP_031582522

Consensus

Larimichthys crocea

Notolabrus celidotus XP 034532653

Archocentrus centrarchus XP_030608958

Micropterus salmoides QFE 32160

Morone saxatilis XP-035530986

Anoplopoma fimbria ACQ58279

Cyclopterus lumpus XP 034412858

Poecilia mexicana XP_014831463

Stegastes partitus XP_008303506

Acanthochromis polyacanthus XP_022077912

Amphiprion ocellaris XP_023136616

Oreochromis aureus XP_031582522

Consensus
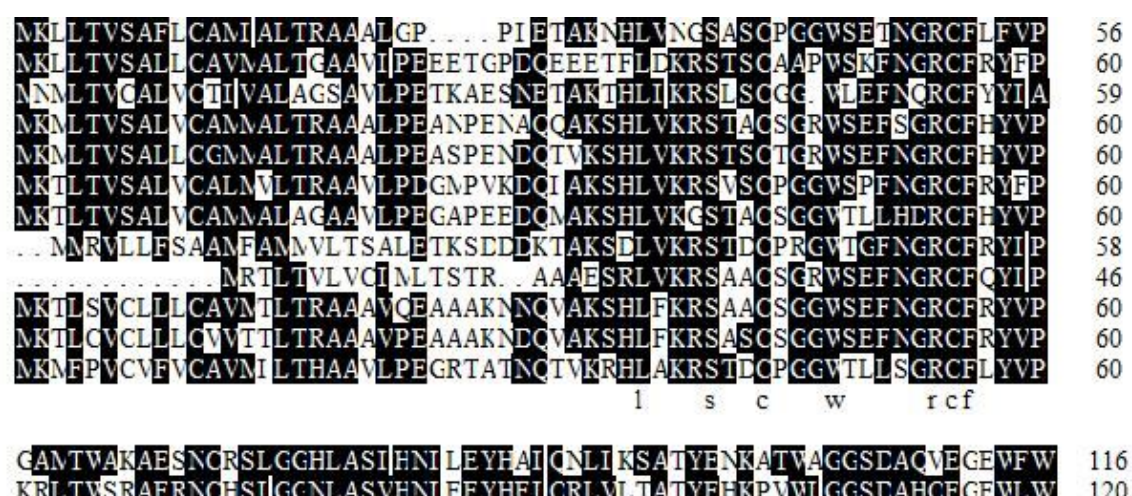

KPNSWALAERSONSLGGHLASVHNFNEYHELCRLI LHFSHEYKETWI GGSEACQENHWIW 119 KPNTWA AEKNCESMGCNLASVHNLLEYHEI|CRLI NSASYLYTVTWI GGSEACEENQWFW 120 RPNTWAKAEKNQLSNGCNLASVHTELEYHEI CRLI NSASYEHKETWI|GGSEACEENQWFW 120 RPLTWAKAEKNCESMGCNLASVHNI LEYHEI CRLI LSGSHEYKCTWVGGSDACEEKQWFW 120 RALRWAEAEKHOVFMGCNLASVHSAQEYHSI QALNI STSHCYKETWIGGSLAEEEKQWFW 120 QPN SWARAEKNCOSNKANLASVHNNEEYHEI CRLI I SASHEYKKTWI GGSDACECNHWFW 118 RSL SWARAERNCOSLGCNLASVHNI NEYCEI CRLI NTVSYEYKETWI GGSLACEENOWLW 106 KANKWATAEKNCCALGGHLASVRDATEYSVI|CKLI L TASYCHNPTWI GGSLACQCEGTFLW 120 RPNTWAKAEKNCCAFGCNLASVHCI TEYHELCRLI NTASYEYKETWI GGSDACEENVFLW 120 GPNTWAKAERNOLSNGANLASVHSI TEYHGICHNI TATHCNQETWI GGSLACEENAWLW 120

$$
\text { w a c las ey q w g w a w }
$$

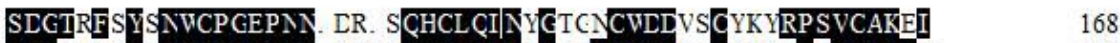

SLCSCVSYTNWCPEPNN. HG. HCHCLCN NWCEKCWLDL SCAKRLPFVCAKRT 172

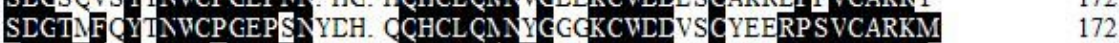

ILGTPFNYL NWOGGEPNNGG. RCNCLCI|NHCLQKCWDDYOCLFRKPSVCAKKI 173

SDGTPFNYNNCPGEPNNHSG. RCSCLCI|NHCAEKCWDDYHCHFKKPSVCVKKI 173

ALGTPFRYLNWCREPN NSR. RCHCLCVNHCAEKCWDDVECYLRKPSVCAKKI 173

SLGTPFHYLNWOSGEPNNNH. . QCNCLCN NYCADKCWDDLHCSROKPSVCAKKK 172

I DGTPFL YTNCP GEPNNHGRRKOLCLCN NHCLHKCWDDVGCHRPKP SVCAKKV 172

SLGTPFI YUNCPGEPNDHNG. ACHCLRI|NHAAQKCWDDF dCHTPKPSVCAKKI

TLGTPFHYTSWCPGEPNNNMV. NCHCICANYNSKCWDLCKCWVYLPSVCGKNI 173

SLCRPFHYTWCPGEPN NGRT. ICHCVCN NFCLTKCWLDL QOSYRRP SVCAKKI 173

TLGNSFQYSNWCPGEPNNLRR. NCHCLCI|NHSGSKCWDDVGCCVHRPSVOVKKM 173

$\mathrm{dg}$ y uc ep $\quad$ q $\mathrm{n}$ ind $\mathrm{c}$ p vc

\section{Figure 1}

The full-length cDNA of ISP2 (GenBank accession number: 2370265) was 861 bp, including a 77 bp 5'untranslated region (UTR), a 301 bp 3'-UTR with an AATAAA signal and a poly (A) tail, and a 507 bp open reading frame (ORF) encoding a putative protein with 168 amino acid residues, which contains a putative signal peptide with 18 amino acid residues 

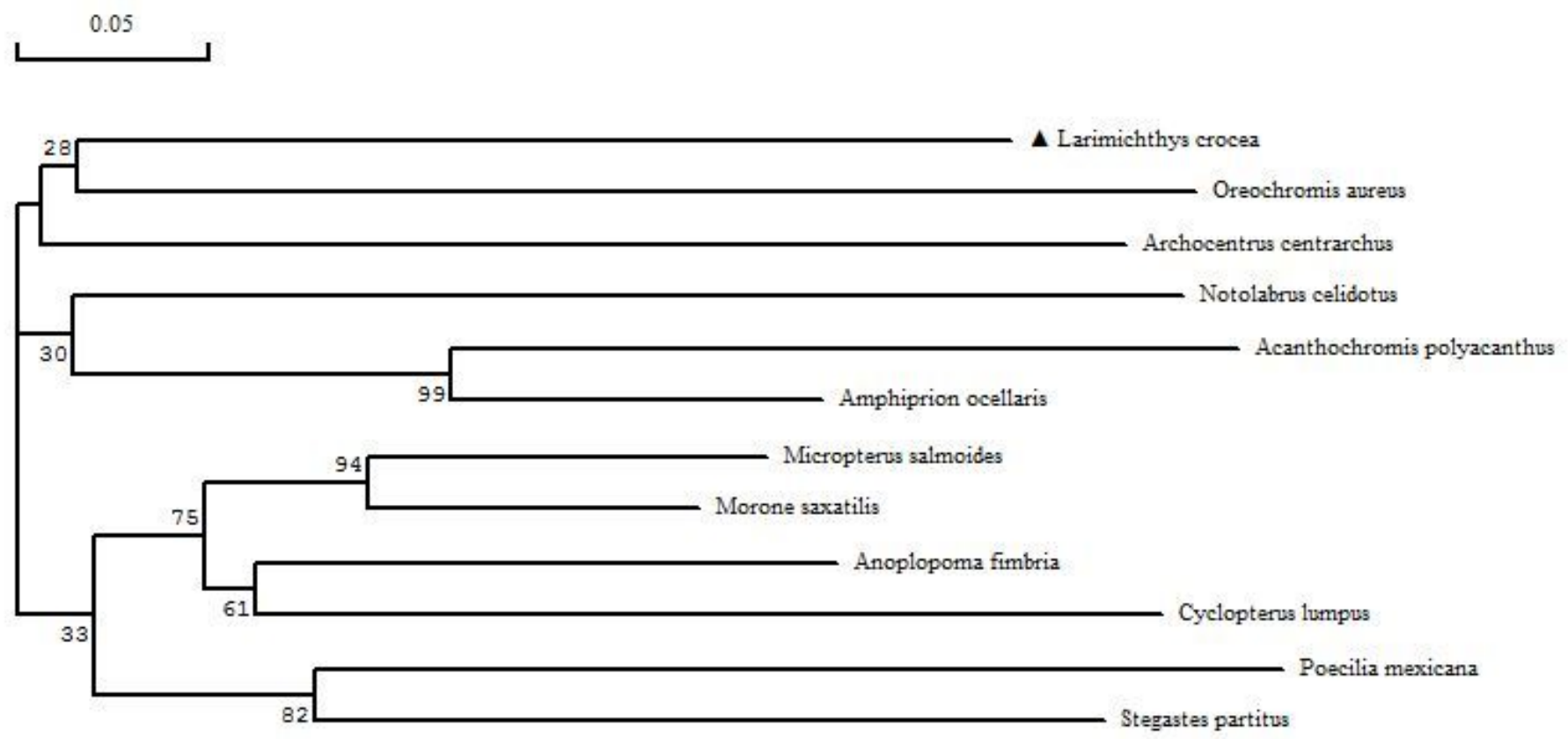

Figure 2

The phylogenetic tree constructed in this study was based on the ISP2 amino acid sequences of 12 fish species 

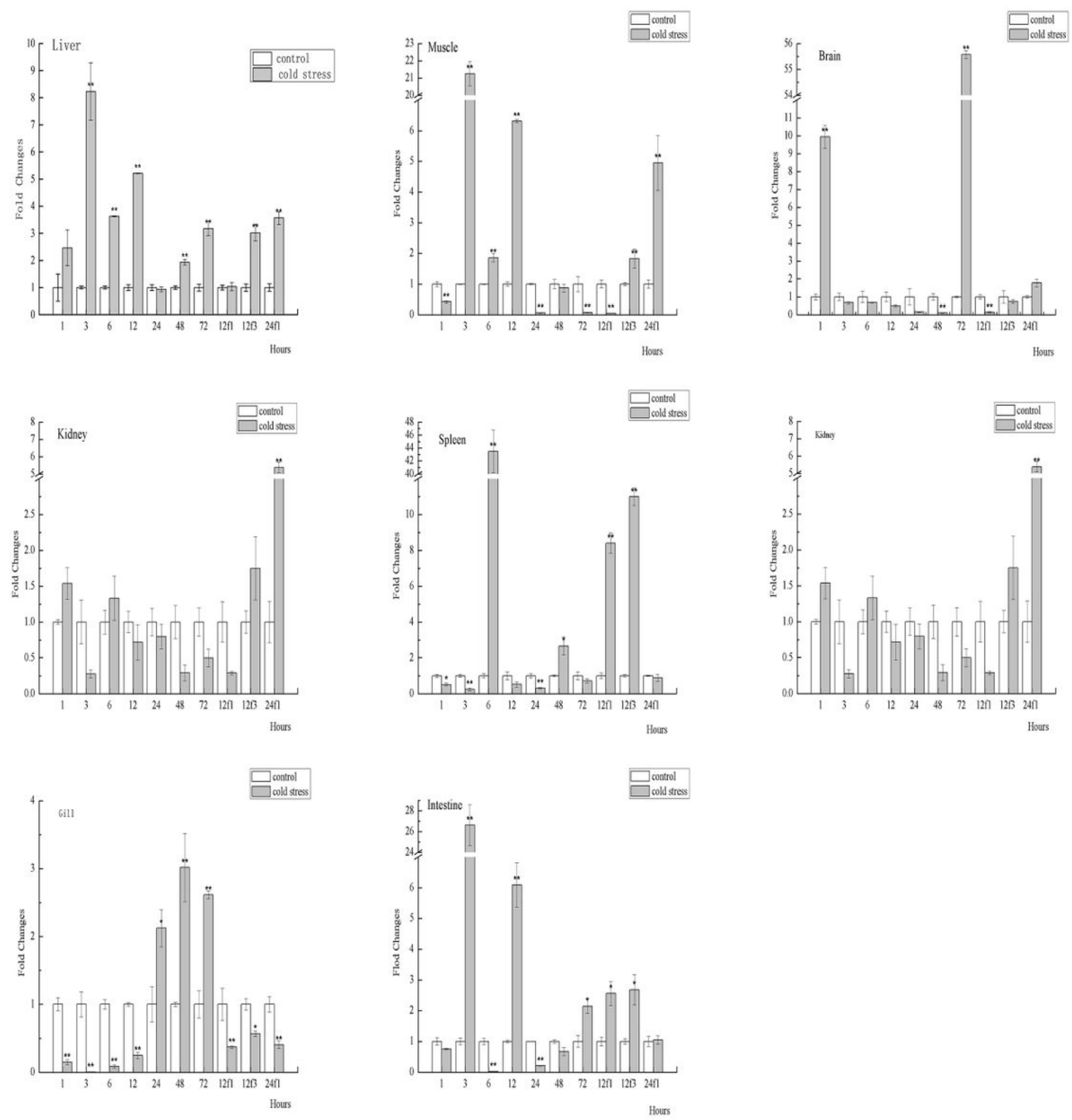

Figure 3

The spatiotemporal expression levels of ISP2 in large yellow croaker under acute cold stress 

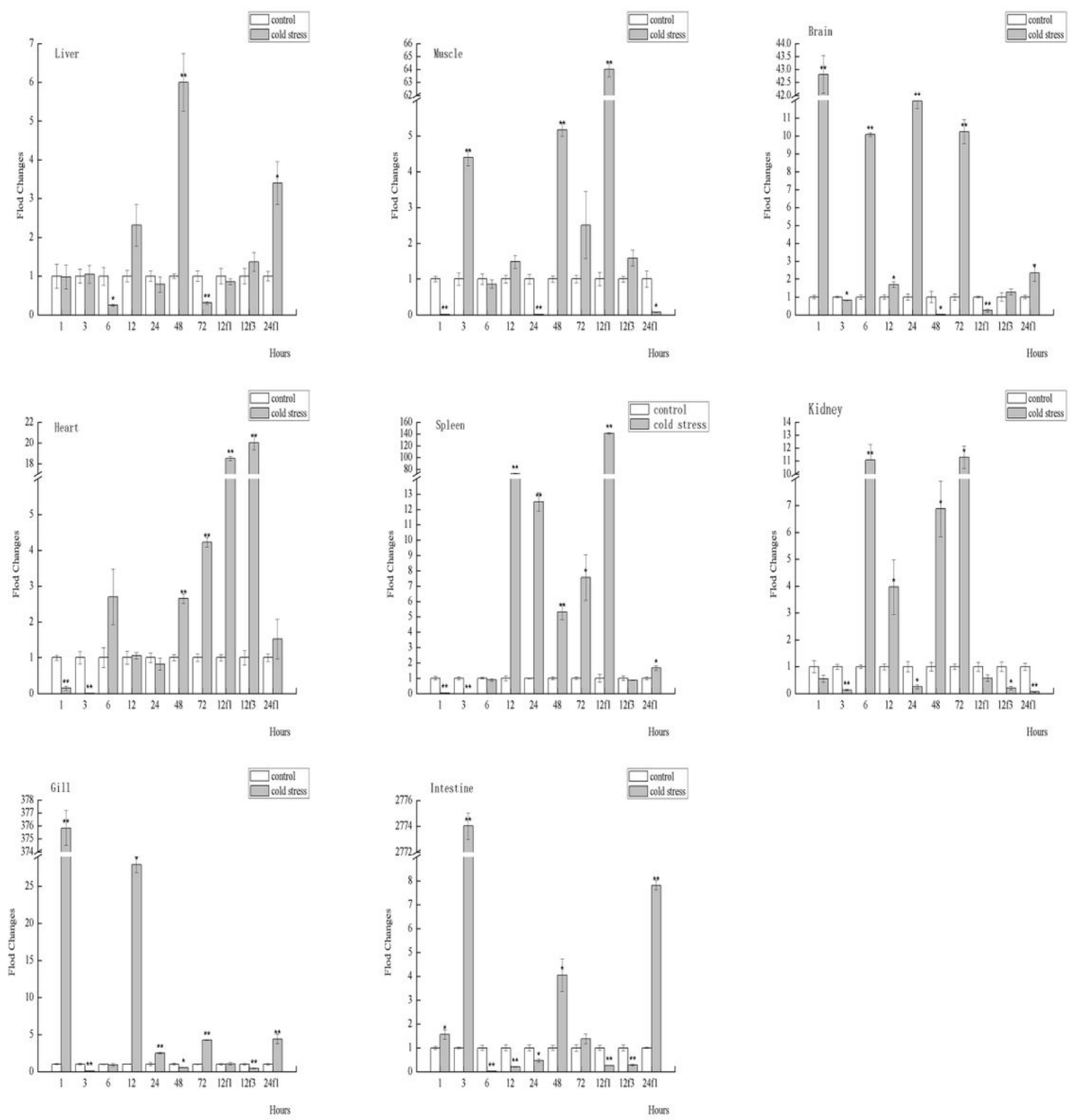

Figure 4

The spatiotemporal expression levels of ISP4 in large yellow croaker under acute cold stress 